\title{
State Aid and Brexit: Reality Slowly Dawns
}

\author{
George Peretz QC *
}

\section{Introduction}

Like many other issues raised by Brexit, the debate in the United Kingdom on what rules on State aid it should adopt after it finally leaves the EU has gone through a number of stages:

(i) objection: politicians and commentators from various parts of the political spectrum express distaste for the regime (on general grounds of imposing undemocratic restrictions on political and economic choices illustrated by specific actual or hypothetical examples);

(ii) refutation: experts on the rules point out that none of the specific examples given are accurate;

(iii) realisation: politicians realise that the constraints imposed by the rules are largely unavoidable and that the rules are anyway actually in the UK national interest;

(iv) concession: the idea of getting rid of the rules is publicly abandoned;

(v) anxious consideration: politicians and civil servants try to work out how to keep the rules while maintaining the overriding objective of leaving the EU.

The debate on State aid has now gone through those stages.

\section{Stages (i) and (ii): Objection and Refutation}

In an earlier article for this journal ${ }^{1}$ I discussed the role that State aid issues played in the not entirely impressive debate that preceded the referendum vote in June 2016. The main State aid issue that emerged during that period was the future of UK steel factories: the Leave campaign argued that, out of the EU, the United Kingdom would be free to spend money on keeping those factories open without having to worry about EU State aid rules. Although that issue was far from being the most important issue in the campaign, it undoubtedly helped the Leave side.
Many readers of this journal who are trying to understand the UK debate on Brexit (not generally an effort I would recommend to those who want to retain their sanity) may at this stage be rather puzzled. They will know that the vast majority of politicians in the Leave campaign came from the Thatcherite tradition: and they will recall that Mrs Thatcher was not known for enthusiastically spending large amounts of taxpayers' money on struggling industries in poorer regions of the United Kingdom that are unlikely ever to vote Conservative. Indeed, those politicians usually advocate a free-market, small-government, "global Britain", liberated from the EU and able to reduce taxation and slash bureaucratic regulation.

Those puzzled readers need to be introduced to the concept of "Lexit": that is to say, the left-wing case for Brexit. In a normal political environment, Lexit could safely be ignored, given its tiny support within the Labour Party and trade unions and complete lack of support within all other UK centre and centre-left parties: but the United Kingdom is not in normal political times, and adherents of Lexit are not only close to, but arguably include, the leadership of the Labour Party (as matters stand, the only plausible alternative government to the Conservative Party).

Indeed, in a speech ${ }^{2}$ delivered in February, Jeremy Corbyn (the leader of the Labour Party, who nominally - though not entirely enthusiastically or convincingly - campaigned to remain in the EU) cited State aid control as a reason for not wanting to stay, at least in any straightforward way, in the single market after Brexit: -

DOI: $10.21552 /$ estal/2018/1/9

* George Peretz QC, Barrister at Monckton Chambers, London.

1 George Peretz, 'A Star Is Torn: Brexit and State Aid' (2016) 2(15)European State Aid Law Quarterly, 334 - 337, available at <https://doi.org/10.21552/estal/2016/3/4> (last accessed on 30 March 2018).

2 See $<$ http://brexitcentral.com/full-text-jeremy-corbyns-speech -labours-brexit-policy/> 
So we would also seek to negotiate protections, clarifications or exemptions where necessary in relation to privatisation and public service competition directives state aid and procurement rules and the posted workers directive. We cannot be held back inside or outside the EU from taking the steps we need to support cutting edge industries and local business, stop the tide of privatisation and outsourcing or from preventing employers being able to import cheap agency labour to undercut existing pay and conditions.

I would not recommend that readers spend their valuable time trying to work out what Mr Corbyn meant by "protections, clarifications or exemptions": it is not entirely clear that Mr Corbyn himself understood what he meant. But what is clear from this pronouncement is that he was claiming that the State aid rules in some way prevented the United Kingdom from supporting "cutting edge industries and local business".

In questions put to him after the speech, one journalist raised an observation the present writer had made on social media earlier that day pointing out that most EU Member States grant more State aid per head than does the United Kingdom (including Scandinavian countries often held up as a model by Mr Corbyn's supporters).

Mr Corbyn's reply was not entirely impressive as an analysis of the State aid rules. He mentioned four things: postal services; water; railways; and banks. However, on postal services, water, and railways, $\mathrm{Mr}$ Corbyn's concern seemed to be not so much about State aid as about objections to liberalisation and possible controls on nationalisation. As for banks, Mr Corbyn seemed to believe that the Commission's requirement that large parts of the Royal Bank of Scotland be sold off after its rescue and nationalisation by the UK Government in 2008 stemmed from a dis-

3 See <http://renewal.org.uk/blog/eu-law-is-no-barrier-to-labours -economic-programme> (last accessed on 30 March 2018).

4 See <https://www.gov.uk/government/speeches/a-brighter-future -for-farming> (last accessed on 30 March 2018).

5 See European Commission, SA.40720 at <http://europa.eu/rapid/ press-release_IP-16-1904_en.htm > (last accessed on 30 March 2018).

6 See, for example, the Commission's January 2018 slides on the concept of a "level playing field", available at $<$ https://ec.europa .eu/commission/sites/beta-political/files/level_playing_field.pdf> (last accessed on 30 March 2018). like of State-owned banks (rather than the need to address the huge distortion of competition caused by a vast State investment in a failing bank).

In any event, a powerful analysis ${ }^{3}$ by Andy Tarrant and Professor Andrea Biondi of 26 economic measures in the Labour Party's manifesto in the 2017 general election found that only two of them might have had to be notified for clearance by the Commission, with seven falling within existing exemptions and the remainder not amounting to State aid at all.

At the other end of the political spectrum, Michael Gove, the Secretary of State for Environment, Food and Rural Affairs in the current UK government, and a prominent campaigner for Brexit, also gave a speech $^{4}$ in which he denounced the State aid rules, claiming that: -

Of course inside the EU, rules on state aid have prevented us from investing in broadband in a way that is best for the UK.

Readers of this journal will be aware that the fact that a proposition is preceded by the phrase "of course" does not make it true, even if it is stated by a senior Minister. And stage (ii) duly occurred: experts pointed out that the Broadband Guidelines give ample room for State support for the development of broadband services in rural areas (Mr Gove's particular concern) and indeed that the United Kingdom had obtained the Commission's approval for a major package of broadband investment. ${ }^{5}$

\section{Stage (iii): Realisation}

Stage (iii) (realisation) has taken place in a number of ways. First, it has been clear to anyone looking at the EU negotiating position on the "future relationship" agreement between the United Kingdom and the EU that, for the EU, continued UK compliance with EU State aid rules is a critical part of a "level playing field", 6 and therefore a "red line" for any substantial agreement on trade matters. The United Kingdom is too big and too close for EU politicians to be able to accept, and sell to their national parliaments, a free trading arrangement that does not tie the UK to the same rules on State aid as apply to EU and EEA Member States (or, indeed, to Ukraine and Turkey under their respective agreements with the $\mathrm{EU})$. The present writer observes that the EU's insistence that the United Kingdom comply with State 
aid rules (not an obligation imposed on Canada under CETA) while claiming that the United Kingdom's "red lines" rule out any significant advance on CETA in terms of enjoying any of the benefits of the single market is itself a form of "cherry picking": but the crude reality of the situation is that the EU is in a stronger bargaining position and can get away with a certain amount of hypocrisy, while the United Kingdom cannot.

UK politicians who have reflected on these issues have also realised that that there is a second problem: even on a "no deal" scenario, WTO rules on countervailing measures would permit any other WTO member (the EU, the US) to respond to any subsidy relating to goods (for example, to the steel industry) with countervailing measures - i.e. special tariffs. Any observer of recent events can be in no doubt that both the EU and the US would do so if given cause.

And, finally, there is also the problem that the structure of devolved government to Scotland, Wales and Northern Ireland - involving full financial autonomy, very wide legislative powers and, now, considerable powers over business taxation - was predicated on the assumption that the EU State aid rules would prevent any misuse of those powers in a way that distorted the UK's own internal market: absent those rules, there is nothing to stop (for example) subsidy races between different parts of the United Kingdom or subsidised products (especially, postBrexit, agricultural products) flooding over UK internal borders.

One of the disappointing aspects of Mr Corbyn's speech was that it did not explicitly acknowledge any of those problems: the best that can be said is that the Delphic reference to "protections, clarifications or exemptions" might have been a way of enabling him (were he ever in a position to take real decisions on these issues) to sign up to the State aid rules while claiming consistency with earlier positions. But, on the other side of the UK political divide (and with the exception of Mr Gove), those watching the UK Government's position observed for many months a more or less complete silence on State aid: a silence that could be taken as an acceptance of the inevitable.

The only significant official Government comment on State aid policy post-Brexit has come in the form of evidence given to the House of Lords EU Committee during the preparation of its report ${ }^{7}$ into competition and State aid policy after Brexit (a re- port to which the present writer contributed evidence $\left.^{8}\right)$. The Government explained that the intention of the EU (Withdrawal) Bill (currently before Parliament) was to "preserve the EU State aid rules and to give a UK body the power to police those rules". Its position was summarised in the report (\$\212-213) - and readers will note the brief references to some of the issues discussed above:

212. The Minister was able to comment on the principles informing the Government's consideration of its future policy on State aid. Firstly, she noted that the UK had "always been in the vanguard of supporting open markets", and pointed to the Prime Minister's Florence speech, during which she said: 'Trying to beat other countries' industries by unfairly subsidising one's own is a serious mistake".

213. Secondly, [the Minister] emphasised that the Government wanted to ensure there would be no distortions of competition within the UK, so that "wealthier areas are not simply able to outspend other areas without regard to the interests of the UK as a whole". The Minister was also "very mindful indeed of our responsibility to involve the devolved administrations closely" in discussions on the UK's future State aid policy.

The report itself duly noted not only the EU's "red line" on State aid, but also the points on the scope of WTO anti-subsidy rules and the risk uncontrolled State aid posed to the UK internal market.

One final point on the Conservative Government's thinking on this should be noted (though it is inevitably speculative). Whether you agree with their fears or not, there is no doubt that many Conservative politicians genuinely fear that a Labour Government led by Mr Corbyn would be very left-wing indeed. It has almost certainly not escaped them that, though the State aid rules would not stop a social democratic government in the European tradition from implementing its policies, they would constrain a

7 See $<$ https://publications.parliament.uk/pa/ld201719/ldselect/ Ideucom/67/67.pdf $>$ (last accessed on 30 March 2018).

8 See <http://data.parliament.uk/writtenevidence/ committeeevidence.svc/evidencedocument/eu-internal-market -subcommittee/brexit-competition/written/69979.html> (last accessed on 30 March 2018) and oral evidence at <http://data .parliament.uk/writtenevidence/committeeevidence.svc/ evidencedocument/eu-internal-market-subcommittee/brexit -competition/oral/71322.html> (last accessed on 30 March 2018). 
far-left government determined (for example) to step in with government money to save any failing business.

\section{Stage (iv): Concession}

The Prime Minister's speech on 2 March $^{9}$ formally recognised the position that had been reached (and implicitly overruled Mr Gove's objection to the State aid rules). She said this:

The next hard fact is this. If we want good access to each other's markets, it has to be on fair terms. As with any trade agreement, we must accept the need for binding commitments - for example, we may choose to commit some areas of our regulations like state aid and competition to remaining in step with the EU's.

The UK drove much of the policy in this area and we have much to gain from maintaining proper disciplines on the use of subsidies and on anti-competitive practices.

Furthermore, as I said in Florence, we share the same set of fundamental beliefs; a belief in free trade, rigorous and fair competition, strong consumer rights, and that trying to beat other countries' industries by unfairly subsidising one's own is a serious mistake.

When read with the Government's evidence to the House of Lords EU Committee, discussed above, it is now fairly clear that the Government is prepared to accept the continuance of EU State aid rules after Brexit.

9 See <https://www.gov.uk/government/speeches/pm-speech-on-our -future-economic-partnership-with-the-european-union> (last accessed on 30 March 2018).

10 See the letter from the Minister to Lord Whitty of 28 March 2018, at <http://data.parliament.uk/DepositedPapers/Files/DEP2018 -0337/280318 - Letter Andrew Griffiths to Rt Hon Lord Whitty.pdf $>$. The CMA had, earlier, not shown enormous enthusiasm to be given this role: See <http://data.parliament.uk/ writtenevidence/committeeevidence.svc/evidencedocument/eu -internal-market-subcommittee/brexit-competition/oral/70457 .html> (last accessed on 30 March 2018), Q8 (Lord Currie, Chairman of the CMA): "If there is to be [a State aid] agency, we are not pitching for extra work; let me put it that way. We have enough to do, we have enough responsibilities, we need to expand. Having said that, it is fair to say that the sorts of skills required for enforcing a state aid regime are the sorts of skills that we have. We have no experience in this area, but then, in the United Kingdom, nobody has, because we have not had to administer such a regime. I could see that this might be a task that has our name on it, but let me emphasise that we are not looking to take it on."

\section{Stage (v): Anxious Consideration}

However, that concession leaves a number of important issues unresolved as to how to apply and enforce the State aid rules. The most attractive option would be to "dock" for these purposes to the mechanisms currently used by the EEA/EFTA countries (the EFTA Surveillance Authority and EFTA Court"): that is to say, to join those mechanisms for the purposes of the State aid rules - and perhaps some other purposes - but not (in deference to the United Kingdom's red lines) the EEA more generally. That option could in principle be reconciled with the "red line" on the ending of CJEU jurisdiction in the United Kingdom on the basis that the EFTA Court is not the CJEU: but it depends on the agreement of the exiting EEA States and may well turn out not to be feasible. In any event, the Government is not at the moment, for wider political reasons, in a position to raise the EEA/EFTA arrangements as a solution to anything.

Although the Government has not completely ruled out a solution along those lines, its preferred approach is now clear: it proposes to set up a domestic State aid regime to be administered by the Competition and Markets Authority as an independent State aid authority. ${ }^{10}$ But that announcement raises the following serious issues about the new "domestic enforcement" model.

- First, it needs to be acceptable to the EU as a robust mechanism to ensure UK compliance with its State aid commitments. The only current domestic enforcement models (in the Ukraine DCFTA and in the various Accession agreements) contain a number of mechanisms to ensure that, on all policy questions and questions of interpretation, the domestic authorities and courts enforcing the State aid rules have to follow not just CJEU jurisprudence but also the policy lead of the Commission. Such a subordinate role is unlikely to be acceptable to the United Kingdom (which can rightly point to its good record of State aid compliance and its role in developing the rules over the years). Indeed, the UK Government may well want not to replicate some of the less attractive features of the EU regime, such as its lack of procedural protection for beneficiaries and the automatic, and sometimes effectively penal, requirement to "repay" unlawful aid whatever the actual net benefit obtained by the beneficiary: and it may want to tailor some of the current exemptions and 
guidelines so as to fit the United Kingdom better than some of them do now. But that means that mechanisms need to be devised for managing possible divergences in policy approach or even in the case-law.

- Second, there are serious constitutional problems in setting up a robust State aid framework within the UK's constitutional arrangements. At national level, the idea of an independent body that has authority, essentially on policy rather than pure legal grounds, to order central Government not to spend money (or not to give tax concessions or tax rulings) is difficult to fit into the UK political system, with its traditional emphasis on Ministers' responsibility to Parliament as (apart from the courts) the sufficient, and only acceptable, check on Ministers' ability to exercise power. And to give such an authority the right to control State aid granted in the form of primary legislation would be constitutional anathema. Moreover, the devolution settlement raises further profound issues. The devolved Governments are (of course) currently constrained by EU State aid law: but those Governments will inevitably be concerned that to replace the EU regime with a State aid regime administered from London would alter, in London's favour, the current delicate balance of powers between the various UK governments.

None of those questions have been publicly addressed by the Government. However, decisions will have to be taken soon. So readers can confidently predict further developments over the next few months, as Brexit approaches. 